\title{
Bis(Styryl) Terephthalonitrile-Derived Two-Photon Fluorescence Probe for Mercury Ions in Live Cells and Living Tissues
}

Chibao Huang ${ }^{1 *}$, Guanglian Zhao ${ }^{1}$, Xiaonan Liu ${ }^{2}$, Daohai Zhang ${ }^{3}$, Tingxiang Yuan ${ }^{1}$ and Yang Liu ${ }^{1}$

${ }^{1}$ Chemistry and Chemical Engineering College, Zunyi Normal University, Zunyi 563002, Guizhou, P. R. China

${ }^{2}$ The Hospital Infection Management Section, The Affiliated Baiyun Hospital of Guizhou Medical University, Guiyang, 550014, Guizhou, P. R. China

${ }^{3}$ Research and Development Department, National Engineering Research Center for Compounding and Modification of Polymeric Materials, Guiyang, 550014, Guizhou

P. R. China

\begin{abstract}
A novel two-photon fluorescence probe for $\mathrm{Hg}^{2+}$ derived from bis(styryl)terephthalonitrile as a two-photon fluorophore and bis [2-(2-hydroxyethyl sulfanyl) ethyl] amino group (ionophore) as a novel $\mathrm{Hg}^{2+}$ ligand was developed. The probe possesses small molecule size, large two-photon absorption cross-section (1067 GM) in $\mathrm{H}_{2} \mathrm{O}$, noncytotoxic effect, long-wavelength emission at $588 \mathrm{~nm}$, large Stokes shift (121 nm), excellent photostability, high water-solubility, good cell-permeability, and $\mathrm{pH}$-insensitivity in the biologically relevant range. The probe can selectively detect $\mathrm{Hg}^{2+}$ ions in live cells and living tissues without interference from other metal ions and the membrane-bound probes, and its quenching constant $\left(\mathrm{K}_{\mathrm{sv}}{ }^{\mathrm{TP}}\right)$ is $8.73 \times 10^{5} \mathrm{M}^{-1}$.
\end{abstract}

Keywords: Bis(styryl)terephthalonitrile; Mercury; Cell-imaging; Two-photon fluorescence probe

\section{Introduction}

An insight of selective staining/imaging of specific cellular ions is of paramount importance for a deeper understanding of the character of each ion in a cellular system and their complex biological functions and processes [1-3]. Two-Photon (TP) excitation fluorescence microscopy (TPM), which uses two photons of lower energy as the excitation source, has rapidly evolved into a widely used tool in biological and biomedical research and is popular.

Ion-targeting two-photon excited fluorescence (TPEF) probes have increasingly drawn attention because of the laser light excitation of these probes, which offers number of advantages including deep tissue imaging, minimal photodamage to biological samples and bleaching to the probes, and low interference from the auto-fluorescence of a cell [4-6]. Various TPEF probes have been successfully designed and synthesized for lead ion [7], zinc ion [8-10], silver ion [11,12], glucose [13], cysteine/homocysteine [14], and thiols [15] in the past few years.

Mercury and its derivatives are widely used in industry, which causes adverse environment and health problems [16,17]. Concerns over toxic exposure to mercury provide motivation to explore new methods for monitoring aqueous $\mathrm{Hg}^{2+}$ in living cells. Either in plants or in animals, sensing of $\mathrm{Hg}^{2+}$ has been conducted by means of atomic absorption spectroscopy [18], X-ray microanalysis [19], or ${ }^{203} \mathrm{Hg}^{2+}$ detection which usually needs expensive apparatus and/or sample preparation and pays the price of damaging the living organisms [20]. However, fluorescent chemodosimeters provide a promising way for simple and rapid tracking of $\mathrm{Hg}^{2+}$ in biological systems. But, only a few of these fluorescent probes have been utilized successfully in living cells [21], as fluorescent chemodosimeters for $\mathrm{Hg}^{2+}$ detection are often limited by nonspecific interference from $\mathrm{Cu}^{2+}$ and other competing metal ions [22,23], or are incompatible with aqueous media and living cells [24], and/or delay $\mathrm{Hg}^{2+}$ response [25].

Although many one-photon sensors for mercury ion have been developed [26-29], only a few two-photon fluorescence chemodosimeter for mercury ion were reported [30-32]. But, one among these three probes is used just for bioimaging and has a considerably small $\delta$ value. Thus it can be seen that the development of two-photon fluorescence sensors for mercury ion is not only indispensable to biological chemistry but also really challenging.

Recently, we reported a mercury TPEF probe for $\mathrm{Hg}^{2+}$ derived from 4-methyl-2,5-dicyano-4'-amino stilbene (DCS) as a TP fluorophore and bis[2-(2-hydroxyethyl sulfanyl)ethyl] amino group (HSA) as a novel $\mathrm{Hg}^{2+}$ ligand [33]. Although this probe exhibited excellent selectivity for $\mathrm{Hg}^{2+}$, it was not applied to live cell and living Tissues imaging.

Herein, we extend our earlier work [33] and report a new TPEF probe for $\mathrm{Hg}^{2+}$ derived from bis(styryl) terephthalonitrile as a twophoton fluorophore and bis[2-(2-hydroxyethyl sulfanyl) ethyl]amino group (ionophore) as a novel $\mathrm{Hg}^{2+}$ ligand, which contains two sulfur atoms known as "soft base" capable of chelating so called "soft acid" heavy metal cations, and exhibits a good affinity to $\mathrm{Hg}^{2+}$. We report that $\mathrm{BHg}$ (Figure 1) is capable of imaging $\mathrm{Hg}^{2+}$ ions in live cells without mistargeting and photobleaching problems.

\section{Experimental}

\section{Materials and Methods}

NMR spectra were recorded on a VARIAN INOVA $400 \mathrm{MHz}$ NMR spectrometer. Mass spectral determinations were made on a ESI-Q-TOF mass spectrometry (Micromass, UK). High resolution mass spectra measurements were performed on a GC-TOF mass spectrometry (Micromass, UK). Fluorescence measurements were performed on a PTI-C-700 felix and time-master system. Fluorescence quantum yields were measured using standard methods [34] on airequilibrated samples at room temperature. Quinine bisulfate in 0.05

${ }^{*}$ Corresponding author: Chibao Huang, Chemistry and Chemical Engineering College, Zunyi Normal University, Zunyi 563002, Guizhou, P. R. China, Tel: 0086852-8927159; E-mail: huangchibao@163.com

Received July 05, 2016; Accepted August 28, 2016; Published August 31, 2016

Citation: Huang C, Zhao G, Liu X, Zhang D, Yuan T, et al. (2016) Bis(Styryl) Terephthalonitrile-Derived Two-Photon Fluorescence Probe for Mercury lons in Live Cells and Living Tissues. J Mol Biomark Diagn 7: 303. doi: 10.4172/21559929.1000303

Copyright: $(2016$ Huang C, et al. This is an open-access article distributed under the terms of the Creative Commons Attribution License, which permits unrestricted use, distribution, and reproduction in any medium, provided the original author and source are credited. 
Citation: Huang C, Zhao G, Liu X, Zhang D, Yuan T, et al. (2016) Bis(Styryl) Terephthalonitrile-Derived Two-Photon Fluorescence Probe for Mercury Ions in Live Cells and Living Tissues. J Mol Biomark Diagn 7: 304. doi: 10.4172/2155-9929.1000304

mol L-1 $\mathrm{H}_{2} \mathrm{SO}_{4}(\Phi=0.546)$ was used as a reference [34]. TPEF (twophoton-excited fluorescence) action cross-section spectra were measured according to the experimental protocol established by $\mathrm{Xu}$ and Webb [35], using a mode-locked Ti/sapphire laser that delivers $\sim 80$ fs pulses at $76 \mathrm{MHz}$. Fluorescein $\left(10^{-4} \mathrm{~mol} \mathrm{~L}^{-1}\right.$ in $\left.0.1 \mathrm{~mol} \mathrm{~L}^{-1} \mathrm{NaOH}\right)$, whose TPEF action cross-sections are well-known [35], served as the reference. The quadratic dependence of the fluorescence intensity on the excitation intensity was verified for each data point, indicating that the measurements were carried out in intensity regimes in which saturation or photodegradation does not occur. The measurements were performed at room temperature on air-equilibrated solutions $\left(10^{-5} \mathrm{~mol}\right.$ $\left.\mathrm{L}^{-1}\right)$. The experimental uncertainty on the absolute action cross-sections determined by this method has been estimated to be $\pm 20 \%$ [35]. Absorption spectra were measured on a HP-8453 spectrophotometer. Solvents were generally dried and distilled prior to use. Reactions were monitored by thin-layer chromatography on Merck silica gel $60 \mathrm{~F}_{254}$ precoated aluminum sheets. Column chromatography: Merck silica gel Si 60 (40 $\mu \mathrm{m}$ to $63 \mu \mathrm{m}, 230-400 \mathrm{mesh})$. The $\mathrm{pH}$-dependent fluorescence studies were performed according to the literature [36].

\section{Synthesis}

2,5-bis((E)-4-(bis(2-chloroethyl) amino) styryl) terephthalonitrile (8): Aldehyde 2 (560 mg, $2.28 \mathrm{mmol})$, and $\mathrm{NaH}$ (55 mg, $2.28 \mathrm{mmol}$ ) were dissolved in $3 \mathrm{~mL}$ of tetrahydrofuran (THF), and the solution was cooled to $0^{\circ} \mathrm{C}$ under $\mathrm{N}_{2}$. To this solution, phosphonate 7 (488 mg, 1.14 $\mathrm{mmol}$ ) in $9 \mathrm{~mL}$ of THF was added dropwise. The reaction mixture was stirred for $1 \mathrm{~h}$ at $0^{\circ} \mathrm{C}$, and then for $12 \mathrm{~h}$ at room temperature, followed by the removal of THF under reduced pressure. Water was added to the reaction mixture, and the product was extracted with dichloromethane $(4 \times 10 \mathrm{~mL})$. The organic layer was dried with dry $\mathrm{Na}_{2} \mathrm{SO}_{4}$ followed by evaporation of the solvent. The crude product was separated by column chromatography with a gradient of hexane in dichloromethane $(20 \%$ to $0 \%$ ) and ethyl acetate in dichloromethane (0\% to 20\%). The resulting solid was recrystallized from acetone to give compound 8 (453 mg, 65\%) as a yellow powder.

$$
\text { IR }(\mathrm{KBr}) \mathrm{cm}^{-1}: 2223(\mathrm{C} \equiv \mathrm{N}) \text { and 1594 1348 }(\mathrm{C}=\mathrm{C}) \text {. }
$$$$
\text { HRMS (EI) m/z: } 610.1225 \text { (calcd for } \mathrm{C}_{32} \mathrm{H}_{30} \mathrm{C}_{44} \mathrm{~N}_{4} \text { : 610.1225). }
$$

${ }^{1} \mathrm{H}$ NMR (DMSO-d $\left.{ }^{6}, 400 \mathrm{MHz}\right) \mathrm{ppm}: 8.446$ (s, 2H, Ph), 7.620 (d, $2 \mathrm{H}, \mathrm{J}=16.4 \mathrm{~Hz}, \mathrm{CH}=\mathrm{CH}), 7.498(\mathrm{~d}, 4 \mathrm{H}, \mathrm{J}=8.4 \mathrm{~Hz}, \mathrm{Ph}), 7.054(\mathrm{~d}, 2 \mathrm{H}$ $\mathrm{J}=16.4 \mathrm{~Hz}, \mathrm{CH}=\mathrm{CH}), 6.844(\mathrm{~d}, 4 \mathrm{H}, \mathrm{J}=8.8 \mathrm{~Hz}, \mathrm{Ph}), 3.772\left(\mathrm{t}, 8 \mathrm{H}, \mathrm{J}_{1}=\mathrm{J}_{2}=4.4\right.$ $\left.\mathrm{Hz}, \mathrm{NCH}_{2}\right), 3.712\left(\mathrm{t}, 8 \mathrm{H}, \mathrm{J}_{1}=\mathrm{J}_{2}=2 \mathrm{~Hz}, \mathrm{CH}_{2} \mathrm{Cl}\right)$

Elemental analysis: calculated for $\mathrm{C}_{32} \mathrm{H}_{30} \mathrm{C}_{14} \mathrm{~N}_{4}$ (MW 612.42) C 62.76, H 4.94, Cl 23.16, N 9.15\%; Found C 62.80, H, 4.98, Cl 23.13, N $9.10 \%$.

2,5-bis((E)-4-(bis(2-(2-hydroxyethylthio) ethyl) amino) styryl) terephthalonitrile (BHg): Compound 8 (306 mg, $0.5 \mathrm{mmol})$, 2-mercaptoethanol (172 mg, $2.2 \mathrm{mmol})$, and anhydrous $\mathrm{K}_{2} \mathrm{CO}_{3}(414$ $\mathrm{mg}, 3 \mathrm{mmol}$ ) were dissolved in acetone $(25 \mathrm{~mL})$, then the mixture was refluxed for $24 \mathrm{~h}$ with stirring under $\mathrm{N}_{2}$. The resulting mixture was filtered, and the filtrate was concentrated by evaporating the solvent to get a viscous liquid. The crude product was purified by column chromatography using acetone/dichloromethane to afford compound BHg (335 mg, 86\%) as a red solid. Further purification could be achieved by recrystallization from methanol to give needle solid. $(\mathrm{C}=\mathrm{C})$.

IR $(\mathrm{KBr}) \mathrm{cm}^{-1}: 3422(\mathrm{OH}), 2922(\mathrm{CH}), 2220(\mathrm{C} \equiv \mathrm{N})$ and 1631 1349

$$
\text { HRMS (EI) m/z: } 778.2715 \text { (calcd for } \mathrm{C}_{40} \mathrm{H}_{50} \mathrm{~N}_{4} \mathrm{O}_{4} \mathrm{~S}_{4}: \text { 778.2715). }
$$

${ }^{1} \mathrm{H}$ NMR ( $\mathrm{CHCl}_{3}$-d, $\left.400 \mathrm{MHz}\right)$ ppm: 8.442 (s, 2H, Ph), 7.620 (d, 2H, $\mathrm{J}=16.0 \mathrm{~Hz}, \mathrm{CH}=\mathrm{CH}), 7.513(\mathrm{~d}, 4 \mathrm{H}, \mathrm{J}=8.8 \mathrm{~Hz}, \mathrm{Ph}), 7.055(\mathrm{~d}, 2 \mathrm{H}, \mathrm{J}=16.0$ $\mathrm{Hz}, \mathrm{CH}=\mathrm{CH}), 6.789(\mathrm{~d}, 4 \mathrm{H}, \mathrm{J}=8.4 \mathrm{~Hz}, \mathrm{Ph}), 4.918(\mathrm{t}, 8 \mathrm{H}, \mathrm{J}=4.8 \mathrm{~Hz}, 4 \times$ $\mathrm{OCH} 2), 3.633\left(\mathrm{t}, 8 \mathrm{H}, \mathrm{J}_{1}=\mathrm{J}_{2}=6.0 \mathrm{~Hz}, 4 \times \mathrm{NCH}_{2}\right), 2.791\left(\mathrm{t}, 8 \mathrm{H}, \mathrm{J}_{1}=6.8 \mathrm{~Hz}\right.$, $\left.\mathrm{J}_{2}=7.6 \mathrm{~Hz}, 4 \times \mathrm{SCH}_{2}\right), 2.728\left(\mathrm{t}, 8 \mathrm{H}, \mathrm{J} 1=6.8 \mathrm{~Hz}, \mathrm{~J}_{2}=6.4 \mathrm{~Hz}, 4 \times \mathrm{SCH}_{2}\right)$, $2.564(\mathrm{~s}, 4 \mathrm{H}, 4 \times \mathrm{OH}) .{ }^{13} \mathrm{C}$ NMR $\left(\mathrm{CHC}_{13}-\mathrm{d}, 100 \mathrm{MHz}\right) \mathrm{ppm}: 147.68$ 138.02, 134.96, 129.36, 128.88, 123.48, 117.03, 116.12, 113.15, 111.64, $61.23,50.69,34.11,28.69$.

Elemental analysis: calculated for $\mathrm{C}_{40} \mathrm{H}_{50} \mathrm{~N}_{4} \mathrm{O}_{4} \mathrm{~S}_{4}$ (MW 779.11) C 61.66, H 6.47, N 7.19, O 8.21, S 16.46\%; Found C 61.71, H 6.54, N 7.16, O $8.17, \mathrm{~S} 16.42 \%$.

\section{Results and discussion}

\section{Designand synthesis of 2,5-bis((E)-4-(bis(2-(2-hydroxyethylthio) ethyl) amino) story) terephthalonitrile (BHg)}

2,5-dibromo-p-xylene (4) [37], 2,5-dimethyl-terephthalonitrile (5) [37], 2,5-bis(bromomethyl)terephthalonitrile (6) [37],1,4-Bis(diethylphosphorylmethyl)-2,5-dicyanob-benzene (7) [38] and 4-[Bis(2-chloro-ethyl) amino] benzaldehyde (2) [39] were synthesized according to literature procedures. The nucleophilic substitution of 8 and 2-mercaptoethanol gave $\mathrm{BHg}$ in high yield (86\%) (Scheme 1). In the reaction of 8 and 2-mercaptoethanol, the substitution of no hydroxy group but mercapto group for chloro group was observed, because the nucleophilic strength of mercapto group is superior to that of hydroxy group.

\section{Selectivities of Sensor BHg for Metal Ions}

The solubility of BHg in water was $576 \mu \mathrm{M}$, which is sufficient to stain the cells (Supplementary Figure S1), Supporting Information (SI)). To obtain insight into the binding properties of $\mathrm{BHg}$ toward metal ions, the fluorescent spectrum changes were investigated upon addition of various metal ions $\mathrm{Ag}^{+}, \mathrm{Ca}^{2+}, \mathrm{Cd}^{2+}, \mathrm{Cr}^{3+}, \mathrm{Fe}^{3+}, \mathrm{Co}^{2+}, \mathrm{Ni}^{2+}, \mathrm{Fe}^{2+}, \mathrm{Na}^{+}$, $\mathrm{Cu}^{2+}, \mathrm{Zn}^{2+}, \mathrm{Mn}^{2+}, \mathrm{Mg}^{2+}, \mathrm{Hg}^{2+}, \mathrm{Pb}^{2+}, \mathrm{K}^{+}$, and $\mathrm{Ba}^{2+}$ ) to $30 \mathrm{mM}$ MOPS buffer $(100 \mathrm{mM} \mathrm{KCl}, 10 \mathrm{mM}$ EGTA, pH 7.2. EGTA=ethylene glycol bis(2-aminoethyl ether) $\mathrm{N}, \mathrm{N}, \mathrm{N}^{\prime}, \mathrm{N}^{\prime}$-tetraacetic acid, and $\mathrm{MOPS}=3$ (morpholino) propanesulfonic acid) of $\mathrm{BHg}$ (Figure 2), respectively. The experimental results suggest that $\mathrm{BHg}$ shows a notable selectivity to $\mathrm{Hg}^{2+}$. As depicted in Figure 2, BHg displays scarcely any response to other metal ions and weak complexation with $\mathrm{Ag}^{+}, \mathrm{Pb}^{2+}$ and $\mathrm{Cu}^{2+}$. The highly selective recognition of $\mathrm{BHg}$ for mercury ion can be attributed to two factors. On the one hand, a sulfur atom and $\mathrm{Hg}^{2+}$ are typical "soft base" and "soft acid", respectively; and the very strong affinity between them is quite natural. On the other hand, the nitrogen atom properties and the numbers of sulfur atoms in open chain monoazadithiacrown ether may play an important role in the affinities of nitrogen and sulfur atoms to heavy-metal-ion.

\section{Sensitivity of sensor $\mathrm{BHg}$ to $\mathrm{Hg}^{2+}$ in $\mathrm{UV}-\mathrm{Vis}$, one- and two- photon excited fluorescence spectra}

Notably, upon complexation with $\mathrm{Hg}^{2+}$, two characteristic strong

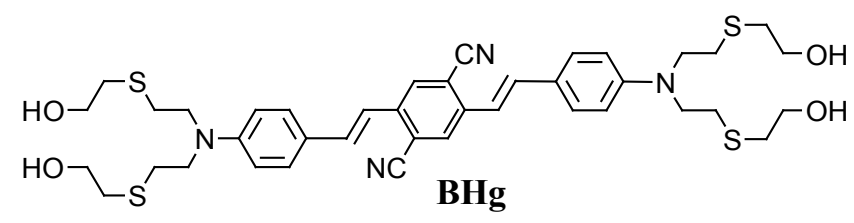

Figure 1: Molecular structure of probe $\mathrm{BHg}$. 
<smiles>OCCN(CCO)c1ccccc1</smiles>

1

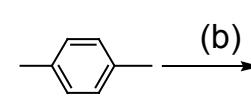

3<smiles>N#Cc1cc(Br)c(Br)c(Br)c1N</smiles><smiles>[2H]c1cc(/C=C/c2ccc(N(CCCl)CCCl)cc2)c(N)cc1/C=C/c1ccc(N(CCCl)CCCl)cc1</smiles>

(g)<smiles>Cc1cc(Cc2ccc(N(CCSCCO)CCSCCO)cc2)cc2nc(N(CCSCCO)c3ccc(C=Cc4ccc(Br)cc4)cc3)ccc12</smiles>

BHg

Scheme 1: Synthetic procedures of compound $\mathrm{BHg}$ (reagent and conditions: (a) $\mathrm{POCl}_{3} / \mathrm{DMF}, 90^{\circ} \mathrm{C}, 2 \mathrm{~h}(95 \%)$; (b) $\mathrm{Br}_{2} / \mathrm{CH}_{2} \mathrm{Cl}_{2}$, no light, $20^{\circ} \mathrm{C}, 24 \mathrm{~h}(90 \%)$; (c) CuCN/DMF, $150^{\circ} \mathrm{C}, 48 \mathrm{~h}(78 \%) ;\left(\right.$ d) $\mathrm{NBS}^{2} \mathrm{CCl}_{4}, 6 \mathrm{~h}(15 \%) ;(\mathrm{e}) \mathrm{P}(\mathrm{OEt})_{3} /$ toluene, $120^{\circ} \mathrm{C}, 5 \mathrm{~h}(96 \%) ;$ (f) $\mathrm{NaH}$ (2 equiv)/THF, $12 \mathrm{~h}(65 \%) ;(\mathrm{g}) \mathrm{K}_{2} \mathrm{CO}_{3} /$ $\mathrm{MeCN}, \mathrm{HS}\left(\mathrm{CH}_{2}\right)_{2} \mathrm{OH}, 40^{\circ} \mathrm{C}, 12 \mathrm{~h}(86 \%)$.

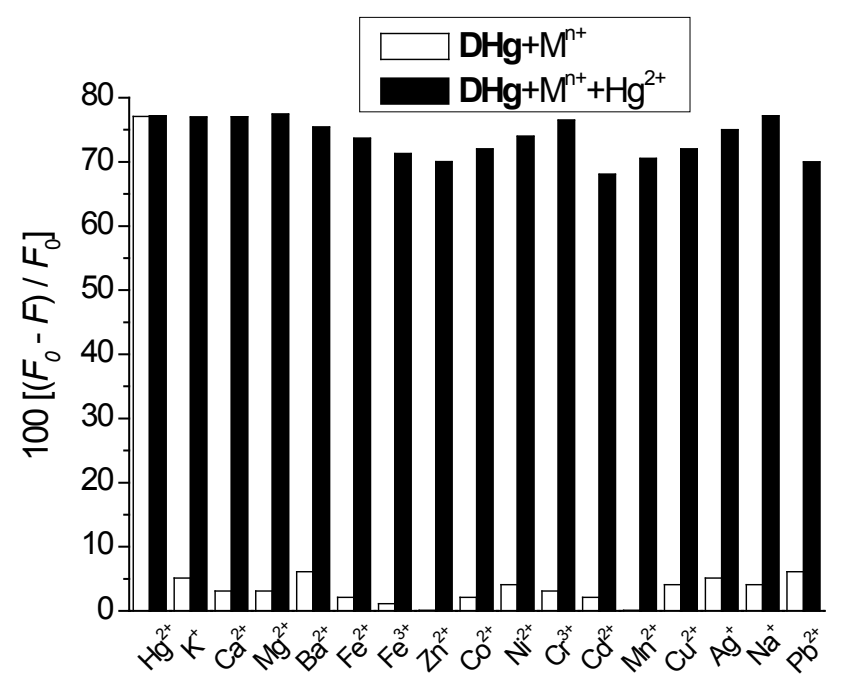

Figure 2: A comparison of the percent quenching of one-photon excited fluorescence of $\mathrm{BHg}(1 \mu \mathrm{M})$ at $588 \mathrm{~nm}$ in the presence of $20 \mathrm{mM}$ for $\mathrm{Zn}^{2+}, \mathrm{K}^{+}$, $\mathrm{Ca}^{2+}, \mathrm{Mg}^{2+}, \mathrm{Ba}^{2+}, \mathrm{Fe}^{2+}, \mathrm{Fe}^{3+}, \mathrm{Pb}^{2+}, \mathrm{Co}^{2+}, \mathrm{Ni}^{2+}, \mathrm{Cr}^{3+}, \mathrm{Cd}^{2+}, \mathrm{Mn}^{2+}, \mathrm{Cu}^{2+}, \mathrm{Ag}^{+}, \mathrm{Na}^{+}$and $\mathrm{Pb}^{2+}$ (empty bars) followed by addition of $40 \mu \mathrm{M}$ of $\mathrm{Hg}^{2+}$ (filled bars). These data were measured in $30 \mathrm{mM}$ MOPS buffer (100 mM KCl, $10 \mathrm{mM}$ EGTA, pH 7.2).

absorption bands of BHg transferred from 467 and $269 \mathrm{~nm}$ to 426 and $284 \mathrm{~nm}$, respectively, a hypochromatic shift of $41 \mathrm{~nm}$ and a bathochromic shift of $15 \mathrm{~nm}$ occurred with the cation-binding event, and the absorption band centered at $467 \mathrm{~nm}$ and the absorption band centered at $269 \mathrm{~nm}$ declined and enhanced gradually, respectively (Figure 3). The quenching constant (KsvAb) of $\mathrm{BHg}$ for mercury ion was determined from the absorption-titration curves to be $8.24 \times 105$ $\mathrm{M}^{-1}$ and $4.36 \times 104 \mathrm{M}^{-1}$ at $20^{\circ} \mathrm{C}$ in $30 \mathrm{mM}$ MOPS buffer (Supplementary Figures S1 and S2).

$\mathrm{BHg}$ exhibits a very strong sensitivity to $\mathrm{Hg}^{2+}$ in the $\mathrm{OP}$ and $\mathrm{TP}$ processes (Figures 4 and 5), and the emission band of BHg centered at $587 \mathrm{~nm}$ progressively decreased upon the addition of $\mathrm{Hg}^{2+}$ to the solution. The quenching of $\mathrm{BHg}$ shows a downward non-linear curvature in the Stern-Volmer plot (I587 vs $\left[\mathrm{Hg}^{2+}\right]$ ) in a broader $\mathrm{Hg}^{2+}$ concentration (0 $\mu \mathrm{M}$ to $40 \mu \mathrm{M}$ ) (Supplementary Figures S3-S5) range. The quenching constants $\left(\mathrm{K}_{\mathrm{sv}} \mathrm{OP}\right.$ and $\left.\mathrm{K}_{\mathrm{sv}} \mathrm{TP}\right)$ for $\mathrm{BHg}$ calculated from the OP and $\mathrm{TP}$ fluorescence titration curves (Figures 4 and 5) are $5.25 \times 105 \mathrm{M}^{-1}(2.76$ $\left.\times 104 \mathrm{M}^{-1}\right)$ and $6.94 \times 105 \mathrm{M}^{-1}\left(2.24 \times 104 \mathrm{M}^{-1}\right)$ (Supplementary Figures S1,S3 and S5), respectively; the detection limit of the probe is in the micromolar range. However, in a narrower concentration $(0.10 \mu \mathrm{M}$ to $10 \mu \mathrm{M})$ range, two linear Stern-Volmer plots are obtained with SternVolmer constants of $\mathrm{K}_{\mathrm{sv}} \mathrm{OP}=8.59 \times 105 \mathrm{M}^{-1}$ and $\mathrm{K}_{\mathrm{sv}} \mathrm{TP}=8.73 \times 105 \mathrm{M}^{-1}$ (Supplementary Figures S1, S4 and S6). BHg is strongly fluorescent in $\mathrm{CH}_{2} \mathrm{C}_{12}(\Phi=0.83)$ and $\mathrm{H}_{2} \mathrm{O}(\Phi=0.62)$. This means that $\mathrm{BHg}$ can serve as a good sensor for mercury ion applied to OPF and TPF detection.

\section{Job's plot for $\mathrm{BHg}-\mathrm{Hg}^{2+}$ complex}

For the complexation ratio between the ligand and the metal ion,

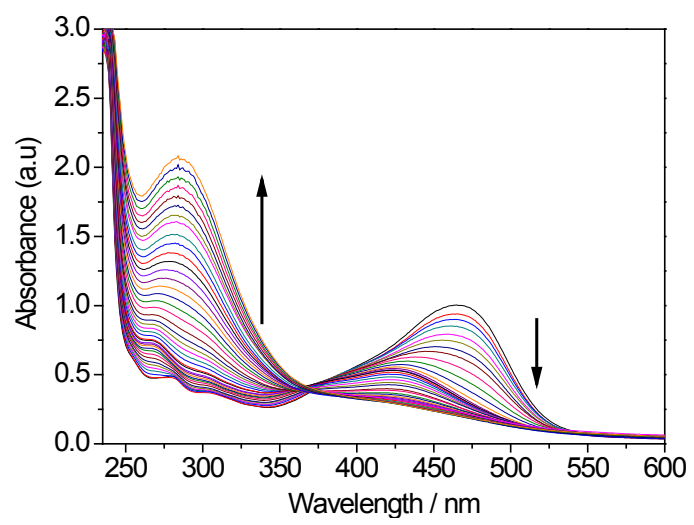

Figure 3: The absorption spectra of $\mathrm{BHg}(10 \mu \mathrm{M})$ in $30 \mathrm{mM}$ MOPS buffer (100 $\mathrm{mM} \mathrm{KCl}, 10 \mathrm{mM}$ EGTA, pH 7.2) after addition of $\mathrm{Hg}^{2+}(0 \mu \mathrm{M}$ to $40 \mu \mathrm{M})$.

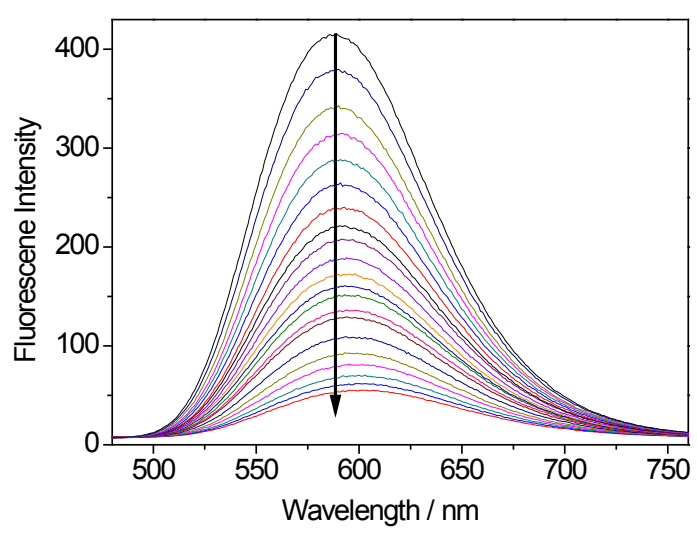

Figure 4: OP emission spectra of $\mathrm{BHg}(1.0 \mu \mathrm{M})$ in $30 \mathrm{mM}$ MOPS buffer (100 $\mathrm{mM} \mathrm{KCl}, 10 \mathrm{mM}$ EGTA, $\mathrm{pH}$ 7.2) after addition of $\mathrm{Hg}^{2+}(0 \mu \mathrm{M}$ to $40 \mu \mathrm{M})$. 
Citation: Huang C, Zhao G, Liu X, Zhang D, Yuan T, et al. (2016) Bis(Styryl) Terephthalonitrile-Derived Two-Photon Fluorescence Probe for Mercury Ions in Live Cells and Living Tissues. J Mol Biomark Diagn 7: 304. doi: 10.4172/2155-9929.1000304

a Job plot experiment was conducted by varying the concentration of both $\mathrm{BHg}$ and $\mathrm{Hg}^{2+}$. Solutions of $\mathrm{BHg}$ and $\mathrm{Hg}^{2+}$ in $30 \mathrm{mM}$ MOPS buffer in different mole fractions were prepared by mixing $\mathrm{BHg}$ and $\mathrm{Hg}^{2+}$ in $\mathrm{H}_{2} \mathrm{O}$ in appropriate ratios while maintaining the total concentration to $1.0 \mu \mathrm{mol} \mathrm{L}{ }^{-1}$. The absorbance of each solution at $467 \mathrm{~nm}$ was measured. The concentration of $\mathrm{BHg}-\mathrm{Hg}^{2+}$ complex for each solution was calculated by using the UV absorption data and the quenching constant (Supplementary Figure S4). The plot of (complex) vs the mole fraction of $\mathrm{Hg}^{2+}$ shows a maximum when the mole fraction is 0.67 , indicating that $\mathrm{BHg}$ is coordinated with $\mathrm{Hg}^{2+}$ with 1:2 stoichiometry in water solution (Supplementary Figure S7-S13).

Two-photon absorption cross section of BHg versus twophoton excited wavelength

$\delta$ of $\mathrm{BHg}$ was determined by using the two-photon-induced fluorescence measurement technique [35]. As expected, $\delta$ of $\mathrm{BHg}$ decreased 2.7-fold from 1067 to $294 \mathrm{GM}$ upon the addition of $20 \mu \mathrm{M}$ $\mathrm{Hg}^{2+}$ to the solution (Figure 6). TP excitation of $\mathrm{BHg}$ produced similar emission spectra compared to OP excitation. Likewise, its two-photon excitation spectra are analogous to the OP absorption spectra, and it had a TP excitation maximum at $810 \mathrm{~nm}$. When excess $\mathrm{Hg}^{2+}$ was added, $\delta$ decreased even further, probably because the electrondonating ability of the aromatic amino moiety is attenuated upon complexation.

\section{One-Photon Fluorescence Spectra of Sensor BHg versus pH}

The fluorescence of $\mathrm{BHg}$ was also slightly weakened by protonation of the tertiary amine in the bis(styryl)terephthalonitrile skeleton upon $\mathrm{pH}<4.5$ or so, and remained unchanged at $\mathrm{pH} 4.5-13$ (Figure 7 ). The enhancement of the fluorescence at high $\mathrm{pH}$ and quenching by $\mathrm{H}^{+}$and $\mathrm{Hg}^{2+}$ are consistent with a ICT mechanism from the aromatic amines. Therefore, $\mathrm{BHg}$ is $\mathrm{pH}$-insensitive in the biologically relevant $\mathrm{pH}$ range.

\section{Two-photon Scanning Microscopy Imaging}

For two-photon in vitro imaging, cells were imaged in the tissue culture chamber $\left(5 \% \mathrm{CO}_{2}, 37^{\circ} \mathrm{C}\right)$ using a Zeiss 510 LSM (upright configuration) confocal microscope equipped with a femtosecondpulsed Ti:sapphire laser (Mira 900-F, Coherent). The excitation beam produced by the femtosecond laser, which was tunable from 700 $\mathrm{nm}$ to $1100 \mathrm{~nm}\left(\lambda_{\mathrm{ex}}=810 \mathrm{~nm}, \sim 1.5 \mathrm{~W}\right)$, passed through an LSM 510 microscope with HFT 650 dichroic (Carl Zeiss, Inc.) and focused onto the coverslip-adherent cells using a $63 \times$ oil immersion objective (NA

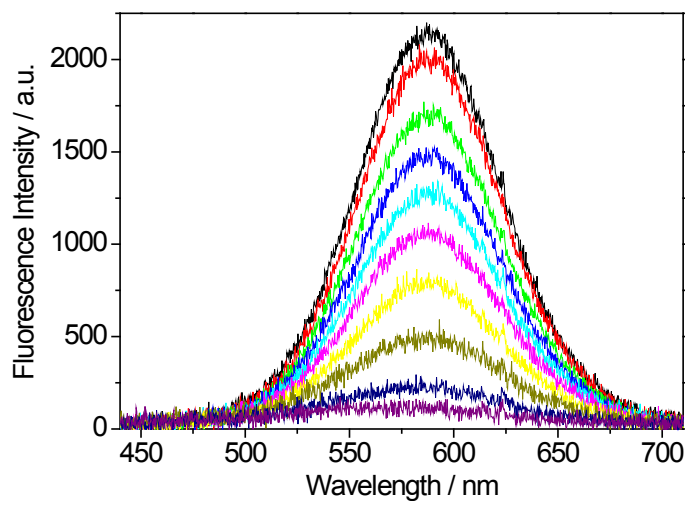

Figure 5: TP emission spectra of $\mathrm{BHg}(1.0 \mu \mathrm{M})$ in $30 \mathrm{mM}$ MOPS buffer (100 $\mathrm{mM} \mathrm{KCl}, 10 \mathrm{mM}$ EGTA, $\mathrm{pH} 7.2)$ after addition of $\mathrm{Hg}^{2+}(0 \mu \mathrm{M}$ to $40 \mu \mathrm{M})$.
1.4). The NLO META scan head allowed data collection in $10.7 \mathrm{~nm}$ windows at $610 \mathrm{~nm}$, and a bypass filter of $550 \mathrm{~nm}$ to $650 \mathrm{~nm}$ was used for collection of the emission light.

Details of the preparation of the mouse fibroblast culture are given in the SI. The TPM images of mouse fibroblast labeled with $\mathrm{BHg}$ showed very strong TPF at $550 \mathrm{~nm}$ to $650 \mathrm{~nm}$ (Figure 8a), and the high contrast and good resolution were observed, indicating $\mathrm{BHg}$ has a considerably desired cell-imaging effect and good cell-permeability. After addition of $20 \mu \mathrm{M} \mathrm{Hg}^{2+}$ to the imaging solution and the incubation at $37^{\circ} \mathrm{C}$ under $5 \% \mathrm{CO}_{2}$ for $15 \mathrm{~min}$, the TPF intensity decreased rapidly, and the TPM image became shaded and obscure (Figure $8 \mathrm{~b}$ ). Without interference from the membrane-bound probes (due to no fluorescence at 360 $\mathrm{nm}$ to $460 \mathrm{~nm}$ ) in this visual window, therefore, $\mathrm{BHg}$ can detect $\mathrm{Hg}^{2+}$ concentrations in live cells and has noncytotoxic effect.

To further investigate the utility of this probe in deep tissue imaging, TPM images were obtained from a part of a mouse brain tissue slice incubated with $10.0 \mu \mathrm{M} \mathrm{BHg}$ for $30 \mathrm{~min}$ at $37^{\circ} \mathrm{C}$. Two TPM images were obtained in the same plane at a depth of about $120 \mu \mathrm{m}$. Without the addition of $\mathrm{Hg}^{2+}$, the TPM image was bright (Figure 9a), while, after the addition of $\mathrm{Hg}^{2+}$, the emission was clearly diminished (Figure $9 \mathrm{~b}$ ). This result demonstrate that $\mathrm{BHg}$ is capable of detecting intracellular $\mathrm{Hg}^{2+}$ ions at a depth of $120 \mu \mathrm{m}$ in living tissues by using TPM.

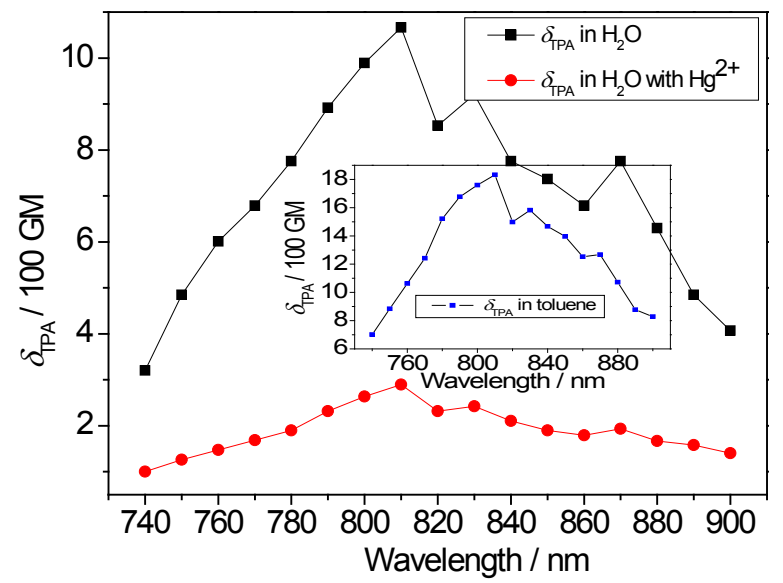

Figure 6: Two-photon excitation spectra of $\mathrm{BHg}(1.0 \mu \mathrm{M})$ before $(\boldsymbol{\square})$ and after $(\Delta)$ addition of 20 equiv of $\mathrm{Hg}^{2+}$ in $30 \mathrm{mM}$ MOPS buffer $(100 \mathrm{mM} \mathrm{KCl}, 10 \mathrm{mM}$ EGTA, pH 7.2).

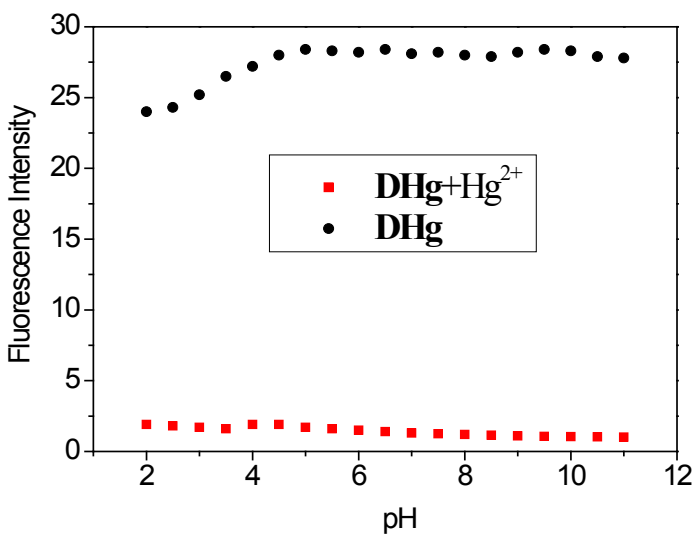

Figure 7: Effect of the $\mathrm{pH}$ on the one-photon fluorescence intensity of $1.0 \mu \mathrm{M}$ $\mathrm{BHg}$ in the presence of $0.0(\bullet)$ and $1.0 \mu \mathrm{M}(\mathbf{\bullet})$ of free $\mathrm{Hg}^{2+}$. pH was adjusted with $\mathrm{HCl}, \mathrm{NaCl}$ and $\mathrm{NaOH}$. The excitation wavelength was $467 \mathrm{~nm}$. 
Citation: Huang C, Zhao G, Liu X, Zhang D, Yuan T, et al. (2016) Bis(Styryl) Terephthalonitrile-Derived Two-Photon Fluorescence Probe for Mercury Ions in Live Cells and Living Tissues. J Mol Biomark Diagn 7: 304. doi: 10.4172/2155-9929.1000304

Page 5 of 6

\section{Building a calibration curve for a $\mathrm{Hg}^{2+}-\mathrm{BHg}$ complex}

All reagents were of the highest purity available and at least of analytical reagent grade. The standard stock solution of lead ( II ) was prepared by dissolving the appropriate amount of mercury nitrate and a small amount of $\mathrm{HNO}_{3}$ in double distilled water. A series of standard solutions of $\mathrm{Hg}^{2+}$ may be prepared with different concentrations by appropriate dilution of the stock solution with water, and are calibrated by volumetric analysis. As seen in (Figure S6) (SI), the TPF intensities of $\mathrm{BHg}(1.0 \mu \mathrm{M})$ show a linear correlation of $\mathrm{Hg}^{2+}$ concentrations from $1.0 \times 10^{-7}$ to $1.6 \times 10^{-5} \mathrm{~mol} \mathrm{~L}^{-1}$. The TPF intensities are plotted versus the solution standard concentrations, and the points should form a straight line. This line, called a calibration curve, shows how changes in TPF intensity with the concentration of a solution.

A calibration curve of the TPF intensities for $\mathrm{BHg}(1.0 \mu \mathrm{M})$ versus the $\mathrm{Hg}^{2+}$ concentrations from $1.0 \times 10^{-7}$ to $1.6 \times 10^{-5} \mathrm{~mol} \mathrm{~L}^{-1}$ was obtained by fitting a linear equation to the data in Table 1 . The calibration curve is equivalent to the equation 1 (Figure 10). In Figure 10, the correlation coefficient $(r)$ and the population correlation coefficient $(\rho)$ are $r=-0.99888$ and $p<0.0001$, respectively. This indicates that there is a good linear correlation between the TPF intensities and the $\mathrm{Hg}^{2+}$ concentrations from $1.0 \times 10^{-7}$ to $1.6 \times 10^{-5} \mathrm{~mol} \mathrm{~L}^{-1}$.

$$
\mathrm{Y}=-2407.07-13536.52 \times \log \left[\mathrm{Hg}^{2+}\right]
$$

\section{Conclusion}

In conclusion, we have developed a TPF probe $\mathrm{BHg}$ with
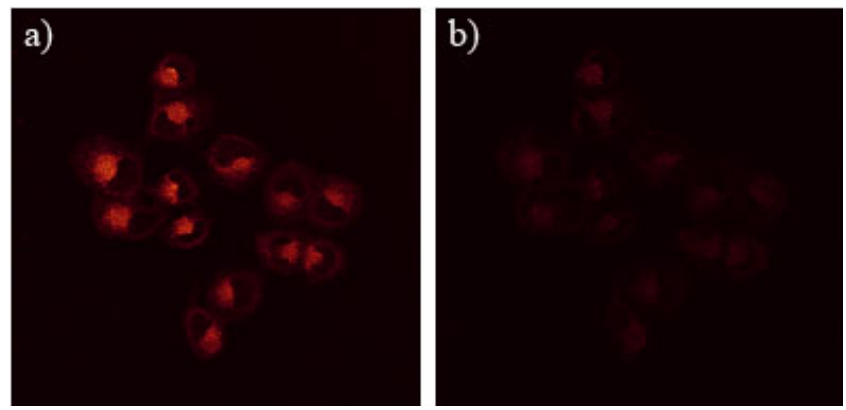

Figure 8: TPM images of $1.0 \mu \mathrm{M}$ BHg-labelled mouse fibroblast collected at $550 \mathrm{~nm}$ to $650 \mathrm{~nm}$, before (a) and after (b) addition of $20 \mu \mathrm{M} \mathrm{Hg}^{2+}$ to the imaging solution. The two-photon excitation fluorescence (TPEF) images were collected upon excitation at $810 \mathrm{~nm}$ with a femtosecond pulse. Cells shown are representative images from replicate experiments $(n=5)$.
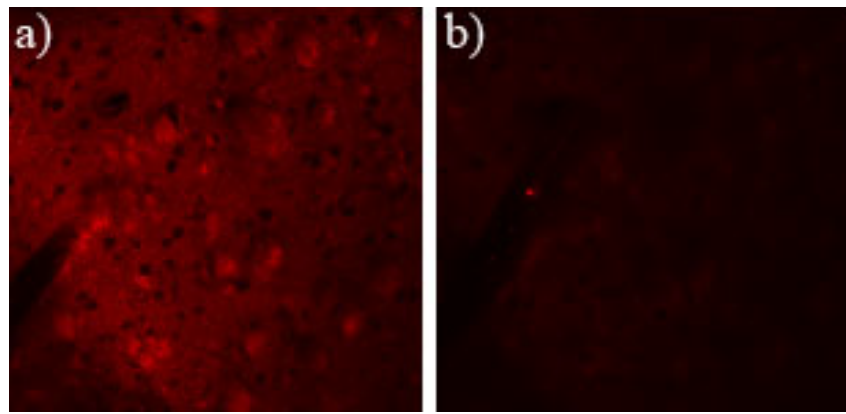

Figure 9: TPM images of a mouse brain tissue slice stained with $10.0 \mu \mathrm{M}$ $\mathrm{BHg}$ at a depth of ca. $120 \mu \mathrm{m}$ with magnification 100x. Before (a) and after (b) addition of $20.0 \mu \mathrm{M} \mathrm{Hg}^{2+}$ to the imaging solution. The two-photon excitation fluorescence (TPEF) images were collected at $550 \mathrm{~nm}$ to $650 \mathrm{~nm}$ upon excitation at $810 \mathrm{~nm}$ with a femtosecond pulse. Cells shown are representative images from replicate experiments $(n=5)$.

\begin{tabular}{|c|c|c|}
\hline Serial number & $X^{a}$ & $Y^{b}$ \\
\hline 1 & $1.00 \mathrm{E}-07$ & 720 \\
\hline 2 & $1.50 \mathrm{E}-07$ & 680.32 \\
\hline 3 & $2.00 \mathrm{E}-07$ & 635.12 \\
\hline 4 & $3.00 \mathrm{E}-07$ & 601.89 \\
\hline 5 & 4.00E-07 & 550.38 \\
\hline 6 & $6.00 \mathrm{E}-07$ & 511.45 \\
\hline 7 & 7.00E-07 & 496.51 \\
\hline 8 & $1.00 \mathrm{E}-06$ & 438.21 \\
\hline 9 & $1.50 \mathrm{E}-06$ & 386.54 \\
\hline 10 & $2.00 \mathrm{E}-06$ & 340.09 \\
\hline 11 & $2.50 \mathrm{E}-06$ & 298.47 \\
\hline 12 & $3.50 \mathrm{E}-06$ & 257.78 \\
\hline 13 & 4.50E-06 & 217.28 \\
\hline 14 & 5.50E-06 & 185.98 \\
\hline 15 & 7.50E-06 & 155.46 \\
\hline 16 & 1.00E-05 & 125.75 \\
\hline 17 & 1.25 E-05 & 100.00 \\
\hline 18 & 1.40 E-05 & 70.00 \\
\hline 19 & $1.60 \mathrm{E}-05$ & 40.00 \\
\hline
\end{tabular}

Table 1: Relative TPF intensities of $\mathrm{BHg}(1.0 \mu \mathrm{M})$ at $587 \mathrm{~nm}$ under different $\mathrm{Hg}^{2+}$ concentrations.

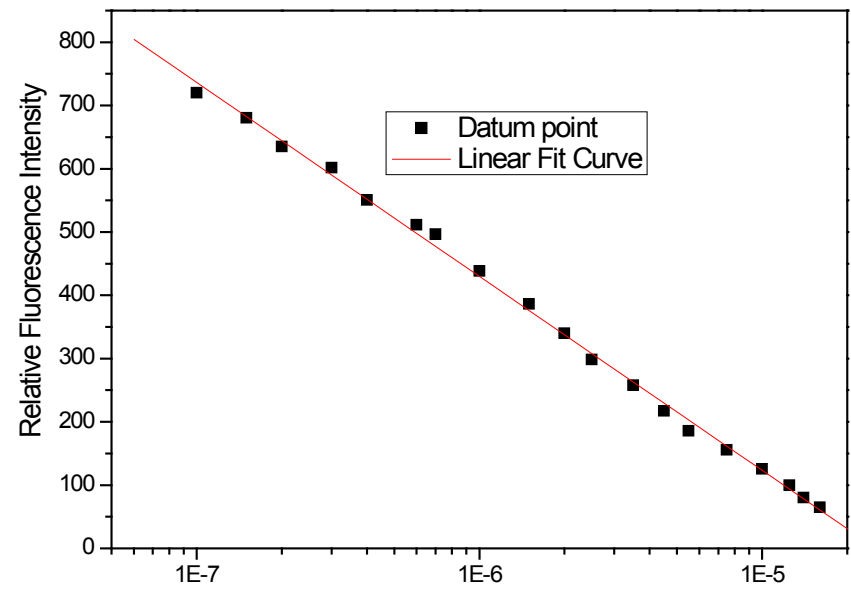

$\left[\mathrm{Hg}^{2+}\right] / \mathrm{mol} \mathrm{L}^{-1}$

Figure 10: The calibration curve of the TPF intensities for $\mathrm{BHg}(1.0 \mu \mathrm{M})$ at 587 $\mathrm{nm}$ versus the $\mathrm{Hg}^{2+}$ concentrations from $1.0 \times 10^{-7}$ to $1.6 \times 10^{-5} \mathrm{~mol} \mathrm{~L}^{-1}$.

small molecule size, large TP absorption cross-section (1067 GM), noncytotoxic effect, long-wavelength emission at $587 \mathrm{~nm}$ (adjacent to the ideal imaging visual window $650 \mathrm{~nm}$ to $900 \mathrm{~nm}$ ), large Stokes shift $(120 \mathrm{~nm})$, excellent photostability, moderate water-solubility and good cell-permeability. $\mathrm{BHg}$ is $\mathrm{pH}$-insensitive in the biologically relevant range, and its quenching constant $\left(\mathrm{K}_{\mathrm{sv}} \mathrm{TP}\right)$ is $8.73 \times 105 \mathrm{M}^{-1}$. This novel probe can selectively detect $\mathrm{Hg}^{2+}$ ions in live cells and living tissues at a depth of $120 \mu \mathrm{m}$ without interference from other metal ions and the membrane-bound probes.

\section{Acknowledgments}

Financial supports from the National Natural Science Foundation of China (Nos. 21562050), the Special Fund Project of the construction of the Eighth Batch of Scientific and Technological Innovation Talent Team in Guizhou Province [No. (2015)4007], Guizhou science and technology fund project (Nos. J[2015]2146, J LKZS [2012]23, J LKZS [2012]13), the Key Project of Education Department of 
Citation: Huang C, Zhao G, Liu X, Zhang D, Yuan T, et al. (2016) Bis(Styryl) Terephthalonitrile-Derived Two-Photon Fluorescence Probe for Mercury Ions in Live Cells and Living Tissues. J Mol Biomark Diagn 7: 304. doi: 10.4172/2155-9929.1000304

Guizhou Province (Nos. KY[2014]296), KY(2013)171), Teaching Contents and Curriculum System Reform Project of Higher Education in Guizhou Province (No. KY [2014] JXGChcb), Project of "15851 Talents Elite Project" in Zunyi City ( (2015) 4007) and the Science and Technology Project of Zunyi city Honghuagang District (No. [2015]18) are deeply acknowledged.

\section{References}

1. Kim HM, Jung C, Kim BR, Jung SY, Hong JH, et al. (2007) A two-photon fluorescent probe for lipid raft imaging: C-laurdan. Chem Int Ed 46: 3460-3463.

2. Kim HM, Kim BR, Hong JH, Park JS, Lee K J, et al. (2007) A two-photon fluorescent probe for calcium waves in living tissue. Chem Int Ed 46: 7445-7448.

3. Kim MK, Lim CS, Hong JT, Han JH, Jang HY, et al. (2010) High-fidelity hydrophilic probe for two-photon fluorescence lysosomal imaging. Chem Int Ed 49: 364-367.

4. Masters BR, Peter TC (2006) Confocal microscopy and multiphoton excitation microscopy: the genesis of live cell imaging. SPIE.

5. So PT, Dong CY, Masters BR, Berland KM (2000) Two-photon excitation fluorescence microscopy. Annu Rev Biomed Eng 2: 399-429.

6. Guo L, Wong MS (2014) Multiphoton excited fluorescent materials for frequency upconversion emission and fluorescent probes. Adv Mater 26: 5400-5428.

7. C. Huang, C. Ding,(2011) Dicyanostilbene-derived two-photon fluorescence probe for mercury ions in live cells and living tissues. Analytica Chimica Acta 699 (2): 198-205

8. Huang C, Qu J, Qi J, Yan M, Xu G (2011) Dicyanostilbene-derived two-photon fluorescence probe for free zinc ions in live cells and tissues with a large twophoton action cross section. Org Lett 13: 1462-1465

9. Sumalekshmy S, Henary MM, Siegel N, Lawson PV, Wu Y, et al. (2007) Design of emission ratiometric metal-ion sensors with enhanced two-photon cross section and brightness. J Am Chem Soc 129: 11888-11889.

10. Kim HM, Seo MS, An MJ, Hong JH, Tian YS, et al. (2008) Two-Photon Fluorescent Probes for Intracellular Free Zinc lons in Living Tissue. Chem Int Ed 47: 5167-5170.

11. Huang C, Ren A, Feng C, Yang N (2010) Two-photon fluorescent probe for silver ion derived from twin-cyano stilbene with large two-photon absorption cross section. Sensors and Actuators B: Chemical 151: 236-242.

12. Huang C, Peng X, Lin Z, Fan J, Ren A, et al. (2008) A highly selective and sensitive two-photon chemosensor for silver ion derived from 3,9-dithia-6azaundecane, Sensors and Actuators B: Chemical.133: 113-117.

13. Tian YS, Lee HY, Lim CS, Park J, Kim HM, et al. (2009) A two-photon tracer for glucose uptake. Chem Int Ed.48: 8027-8031.

14. Zhang M, Yu M, Li F, Zhu M, Li M, et al. (2007) A highly selective fluorescence turn-on sensor for cysteine/homocysteine and its application in bioimaging. J Am Chem Soc 129: 10322-10323.

15. Lee JH, Lim CS, Tian YS, Han J H, Cho BR (2010) A two-photon fluorescent probe for thiols in live cells and tissues. J Am Chem Soc132: 1216-1217.

16. Harris HH, Pickering IJ, George GN (2003) The chemical form of mercury in fish. Science 301: 1203.

17. Harada M (1995) Minamata disease: methylmercury poisoning in Japan caused by environmental pollution. Crit Rev Toxicol 25: 1

18. Palmeira CM, Moreno AJ, Madeira VM (1994) Interactions of herbicides 2,4 $\mathrm{D}$ and dinoseb with liver mitochondrial bioenergetics. Toxicol Appl Pharmacol 127: 50 .

19. Endo T, Sakata M, Shaikh ZA (1995) Mercury uptake by primary cultures of rat renal cortical epithelial cells: 1 . effects of cell density, temperature, and metabolic-inhibitors. Toxicol Appl Pharmacol 132: 36.

20. Bridges CC, Zalups RK (2004) Molecular and ionic mimicry and the transport of toxic metals. Am J Pathol 165: 1385

21. Zhang Z, Wu D, Guo X, Qian X, Lu Z, et al. (2005) Visible study of mercuric ion and its conjugate in living cells of mammals and plants. Chem Res Toxicol 18: 1814.

22. Xu Z, Qian X, Cui J (2005) Colorimetric and ratiometric fluorescent chemosenso with a large red-shift in emission: Cu(II)-only sensing by deprotonation of secondary amines as receptor conjugated to naphthalimide fluorophore. Org Lett 7: 3029 .
23. Martınez R, Espinosa A, Tarraga A, Molina $P$ (2005) $\mathrm{New} \mathrm{Hg}^{2+}$ and $\mathrm{Cu}^{2+}$ selective chromo- and fluoroionophore based on a bichromophoric Azine. Org Lett 7: 5869 .

24. Prodi L, Bargossi C, Montalti M, Zaccheroni N, Su N, et al. (2000) An effective fluorescent chemosensor for mercury ions. J Am Chem Soc 122: 6769.

25. Rurack K, Kollmannsberger M, Resch-Genger U, Daub J (2000) A selective and sensitive fluoroionophore for hgii, agi, and cuii with virtually decoupled fluorophore and receptor units. J Am Chem. Soc 122: 968.

26. Ono A, Togashi H (2004) Möbius Aromatic Hydrocarbons: Challenges for Theory and Synthesis. Angew Chem 116: 4396-4400.

27. Zheng H, Qian ZH, Xu L, Yuan FF, Lan LD, et al. (2006) Switching the recognition preference of rhodamine $b$ spirolactam by replacing one atom Design of Rhodamine B Thiohydrazide for recognition of $\mathrm{Hg}(\mathrm{II})$ in aqueous solution Org. Lett 8: 859-861.

28. Nolan EM, Lippard SJ (2003) A "turn-on" fluorescent sensor for the selective detection of mercuric ion in aqueous media. J Am Chem Soc 125: 14270-14271.

29. Dai H, Liu F, Gao Q, Fu T, Kou X (2011) A highly selective fluorescent senso for mercury ion (II) based on azathia-crown ether possessing a dansyl moiety. Luminescence, 26 : 523-530

30. Wu Y, Dong $Y$, Li J, Huang $X$, Cheng $Y$, et al. (2011) A Highly Selective and Sensitive Polymer-ased Fluorescence Sensor for $\mathrm{Hg} 2+-$ Ion Detection via Click Reaction. Chem Asian J 6: 2725-2729

31. Lim CS, Kang DW, Tian YS, Han JH, Hwang HL, et al. (2010) Detection of mercury in fish organs with a two-photon fluorescent probe. Chem Commun 46: $2388-2390$

32. Bell J, Samb I, Toullec PY, Mongin O, Blanchard-Desce M, et al. (2014 Ultra-sensitive and selective $\mathrm{Hg}^{2+}$ chemosensors derived from substituted 8-hydroxyquinoline analogues. New J Chem 38: 1072-1078

33. Huang C, Fan J, Peng X, Lin Z, Guo, et al. (2008) Highly selective and sensitive twin-cyano-stilbene-based two-photon fluorescent probe for mercury (ii) in aqueous solution with large two-photon absorption cross-section. J Photochem Photobio A: Chem 199 (2-3): 144-149.

34. Eaton DF (1988) Reference materials for fluorescence measurement. J photochem Photobiol Bbiol 2: 523-531.

35. Xu C, Webb WW (1996) Measurement of two-photon excitation cross sections of molecular fluorophores with data from 690 to $1050 \mathrm{~nm}$. J Opt Soc Am B 13: 481-491.

36. Burdette SC, Walkup GK, Spingler B, Tsien RY, Lippard SY (2001) Fluorescent Sensors for $\mathrm{Zn}^{2+}$ Based on a Fluorescein Platform: Synthesis, Properties and Intracellular Distribution. J Am Chem Soc 123: 7831-7841.

37. Huang H, He Q, Lin H, Bai F, Sun Z, et al. (2004) Synthesis and photophysical properties of a novel semiconducting polymer. Polym Adv Technol 15: 84-88.

38. Wenseleers W, Stellacci F, Meyer-Friedrichsen T, Mangel T, Bauer CA, et al. (2002) Five Orders-of-Magnitude Enhancement of Two-Photon Absorption for Dyes on Silver Nanoparticle Fractal Clusters. J Phys Chem B 106: 6853-6863.

39. Wiley RH, Irick G (1961) Notes. 4[N, N-Bis(2-haloethyl) amino]benzaldehyde Derivatives. J Org Chem 26: 593-595. 